\title{
Self-compassion and positive body image: a role for social comparison?
}

\author{
Rachel Andrew*, Marika Tiggemann, Levina Clark \\ From 2013 ANZAED Conference: Inspiring Change: Person and Context \\ Melbourne, Australia. 23-24 August 2013
}

There is continued interest in mindfulness-based therapies for eating disorders, with self-compassion identified as a key psychological construct. Self-compassion has been shown to be associated with positive body image. The aim of the present study was to examine the role of social comparison as a possible mediator of the relationship between self-compassion and both positive body image and body dissatisfaction. Participants were 266 female university students aged 18 to 29 years who completed an online survey containing measures of positive body image, body dissatisfaction, self-compassion and social comparison. Self-compassion was found to be positively related to positive body image and negatively related to body dissatisfaction. Self-compassion was found to be negatively related to social comparison. Importantly, regression analyses showed that, as predicted, social comparison at least partially mediated the relationships between self-compassion and positive body image and body dissatisfaction. The findings add to our theoretical understanding of the precursors of positive body image and provide preliminary evidence for specifically targeting self-compassion and social comparison within prevention programs and mindfulness-based therapies for eating disorders.

This abstract was presented in the Body Image stream of the 2013 ANZAED Conference.

doi:10.1186/2050-2974-1-S1-054

Cite this article as: Andrew et al: Self-compassion and positive body image: a role for social comparison? Journal of Eating Disorders 2013 (Suppl 1):054.
Submit your next manuscript to BioMed Central and take full advantage of:

- Convenient online submission

- Thorough peer review

- No space constraints or color figure charges

- Immediate publication on acceptance

- Inclusion in PubMed, CAS, Scopus and Google Scholar

- Research which is freely available for redistribution
() Biomed Central

* Correspondence: rachel.andrew@flinders.edu.au

School of Psychology, Flinders University, Australia

C 2013 Andrew et al; licensee BioMed Central Ltd. This is an Open Access article distributed under the terms of the Creative Commons 